\title{
Business Librarians: Their Education and Training
}

\section{Lewis-Guodo Liu and Bryce Allen}

\begin{abstract}
Subject expertise has been regarded as an important contributing factor in determining the quality of information services provided in specialized academic libraries. A telephone survey of academic business librarians was conducted to ascertain their level of business education. A survey of instructors of business information courses in library schools was conducted to discover the areas of business considered important in their courses. Results show that a minority of academic business librarians have been educated in business administration. Broad areas of business are considered important for library school course, but specialized and technical areas are considered less important. These results suggest that traditional education and training for business librarians are less than adequate. Partnerships between schools of business and schools of library and information science are suggested as one way to improve levels of business education for business information specialists.
\end{abstract}

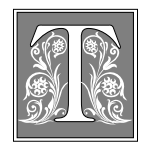

he ability to provide highquality information services depends on many factors. Researchers and practitioners have maintained that subject expertise is one of those factors, particularly in specialized fields such as science, engineering, and business librarianship. The purpose of this investigation was to explore the educational background and professional experience of business librarians. In particular, the authors' focus was on business librarians' formal training in the subject of business. The authors wished to ascertain levels of subject expertise that would prepare business librarians to provide high-quality information service.
Jean-Pierre V. M. Herubel maintained that "Subject expertise can only enhance a librarian's ability to interpret the collections to students and scholars. Public services can make a rich contribution to the educative process when they are performed by librarians who have a solid grounding in a subject disciplines. ${ }^{11}$ Crit Stuart and Miriam A. Drake argued that "Some of our colleagues make the argument that non-scientists can be trained to perform as effectively as librarians with science or engineering degrees. However, without a knowledge of mathematical concepts, basic scientific principles, engineering applications and the communication channels used by scien-

Lewis-Guodo Liu is Business Information Specialist and Associate Professor at Baruch College of the City University of New York; e-mail: lewis_liu@baruch.cuny.edu. Bryce Allen is Associate Professor in the School of Information Science and Learning Technologies at the University of Missouri; e-mail: AllenB@missouri.edu. The authors would like to thank Diana Pratomo for her assistance with the telephone interviews with business librarians. 
tists and engineers to acquire scientific and technical information, the non-science or engineering person begins with a disadvantage that is difficult to overcome." 2 They further argued that "The science or engineering degreed librarian with a grounding in subject materials, practice in scientific and research methods, and a presumed enthusiasm for the subject discipline is more likely to establish valuable relationships with clients and be able to provide effective information services. A librarian with a science or engineering background will have a greater understanding of the client's problem and context and will be able to

The fact that science and engineering and business librarians lack formal education in subject areas has caused concerns about the profession.

evaluate as well as find useful information." ${ }^{3}$ Julie Hallmark interviewed government, academic, and corporate geoscience information specialists regarding the importance of their education in the subject area along with other skills. She concluded that "Participants in the study agreed that a strong science background for geoscience information specialists was highly desirable, if not essential. Some library managers, in fact, stated that they would prefer to hire a geologist and train that person in library and information science than vice versa." ${ }^{4}$ Business librarianship also requires specialized subject knowledge. Shirley Echelman wrote: "To be successful, the business librarian must learn to speak and understand the language of business. He must do this not only to be able to serve his constituents, but also to function as an accepted member of the professional and managerial staff of a modern organization. ${ }^{5}$ Lewis-Guodo Liu pointed out that the emergence of Internet resources and services in business has created a new responsibility for business librarians: "Business librarians have to identify, select, evaluate, and organize business information on the
Internet to meet the information needs of their local patrons." ${ }^{\prime 6}$ Subject knowledge is crucial to carry out these responsibilities.

The consensus reached among special librarians was reflected in the 1996 report to the Special Libraries Association (SLA) board of directors by the Special Committee on Competencies for Special Librarians. It states that the special librarians should have "specialized subject knowledge appropriate to the business of the organization or client." ${ }^{\prime 7}$ Some original research has been conducted to test the assumption of whether subject knowledge improves information access and retrieval. Raya Fidel and Ingrid Hsieh-Yee found that subject knowledge had effects on searches by experienced searchers. ${ }^{8,9}$ Hsieh-Yee specifically observed that "in searching a topic they knew about, they used more of their own terms. The use of these tactics seems sensible and logical. Clearly, when one is not familiar with a topic, more preparation is warranted and more effort should be made for term selection; whereas, while searching in one's own field, it is much easier for experienced searchers to simply rely on their own terms for the search." She also observed that when searching a different, but similar, subject area, experienced searchers with subject knowledge can effectively conduct the search. "Findings on the role of subject knowledge suggest that experienced searchers knew how to cope with their deficiency in this area. Like all good searchers, they took advantage of the thesaurus structure for term suggestions, tried to identify all possible relevant terms (descriptors and nondescriptors), including many more synonyms, combined them in many ways, and monitored their search carefully." 10 Some researchers found that subject knowledge also helps novice searchers. For example, Thomas Jacobson and David Fusani concluded that "Relative to general computer knowledge, for example, our data suggest subject knowledge is of considerable importance and can account for significant amounts of variance in enduser studies."11 
It also can be observed from hiring practices that many libraries require or prefer a law librarian to have a J.D. degree, a science librarian to have formal academic training in the sciences, and a business librarian to have an undergraduate degree in business or an MBA in addition to an MLS degree.

The fact that science and engineering and business librarians lack formal education in subject areas has caused concerns about the profession. A number of surveys were conducted on educational background of science and engineering librarians and business librarians. In 1983, Ellis Mount surveyed sixteen science and technology college and university libraries. ${ }^{12}$ In 1993 Meng Xiong Liu and Wei Wei surveyed science and technology librarians in the University of California and California State University system libraries. ${ }^{13}$ And in 1999, Christopher Hooper-Lane surveyed sixty-seven science and chemistry librarians. ${ }^{14}$ Mount found that 50 percent of surveyed librarians did not possess academic degrees in the sciences; Liu and Wei found that about 62 percent of the surveyed did not have formal educational background in sciences and technologies; and Hooper-Lane found that only 43 percent of librarians who responded to the survey had formal academic degrees in chemistry and that 63 percent had academic degrees in one of the science disciplines. The overall picture shows that science and technology librarians lack formal training and subject knowledge in their subject areas. A 1986 survey conducted by Aubrey Kendrick on the education of business librarians showed that among the 162 respondents, 3.1 percent had undergraduate majors in business administration, 3.1 percent in economics, 1.2 percent in accounting, 1.2 percent in management, 1.2 percent in marketing, and 0.6 percent in finance. Her survey also showed that 17.3 percent had MBA degrees. ${ }^{15}$

TABLE 1

Majors of Business Librarians

\begin{tabular}{lcc} 
rea & Frequency & Percent \\
\hline ences & 82 & 55.8 \\
& 23 & 15.6 \\
al schools & 22 & 15.0 \\
nd engineering & 15 & 10.2 \\
& 5 & 3.4 \\
\hline & 147 & 100.0
\end{tabular}

\section{Survey of Business Librarians Methodology}

The Association to Advance Collegiate Schools of Business (AACSB) is an international accrediting agency for postsecondary programs in business and accounting. Approximately 380 U.S. business schools meet the criteria and are accredited by AACSB. The authors compiled a list of these schools and sampled randomly from it to create a sample of 150 academic institutions. From publicly available information, including the institutions' Web sites, the authors compiled a list of business librarians. These librarians were contacted initially by e-mail, and a time was established for telephone contact. A total of 147 academic business librarians were interviewed by telephone in the fall semester of 2000 and the winter semester of 2001, and their responses form the basis of the analyses and findings reported below.

\section{Results}

The following tables show the survey results. Table 1 shows that a large majority of academic business librarians have undergraduate degrees in disciplines other than business administration. More than 55 percent have undergraduate degrees in the humanities. The second largest group of business librarians is those with undergraduate degrees in social sciences. Only 15 percent of business librarians have undergraduate degrees in business.

Table 2 shows that the pattern of undergraduate minors mirrors that of undergraduate majors. About 55 percent of business librarians have undergraduate 


\begin{tabular}{|lcc|}
\hline \multicolumn{3}{c|}{ TABLE 2} \\
Undergraduate & Minors of Business & Librarians \\
\hline \hline Subject Area & Frequency & Percent \\
\hline Humanities & 52 & 54.7 \\
Business & 15 & 15.8 \\
Social sciences & 14 & 14.7 \\
Professional schools & 11 & 11.6 \\
Science and technology & 3 & 3.2 \\
\hline Total & 95 & 100.0 \\
\hline
\end{tabular}

The authors also found from the survey that business librarians who were interviewed had been in their current positions for an average of eleven years. Table 7 shows the distribution of the length of time academic business librarians reported being in their current positions.

Business librarians reported moving into their

minors in humanities. Only 15.8 percent of business librarians have undergraduate minors in business.

Table 3 demonstrates that virtually all (99.3 percent) respondents have master's degrees in library science, but only thirtyfive (23.8 percent) have master's degrees in economics or business.

Business librarians with doctoral degrees are shown in table 4 . Six respondents have doctoral degrees. Only one has a doctorate in business. Most of the degrees are in the fields of the humanities and social sciences.

Table 5 tabulates the business librarians with second master's degrees in fields other than business or economics. Respondents with second master's degrees from other disciplines (forty-one) outnumbered those with second master's degrees in business or economics (thirty-five).

Another way of obtaining subject expertise in business is to take courses that are not applied toward a degree. Table 6 tabulates the number and type of courses taken by business librarians. Approximately half $(50.3 \%)$ of respondents took courses in business topics that were not applied to formal degrees. current positions from a variety of other library positions. Table 8 tabulates the previous library employment of respondents. It can be observed that most business librarians come from backgrounds of reference service (31.3\%), special libraries $(11.6 \%)$, and technical services $(10.9 \%)$.

\section{Tenure and Publications}

Another way of maintaining and demonstrating expertise in a discipline is to engage in research and publication. Some academic institutions require these activities as a condition of employment. A majority of respondents $(56.5 \%)$ said that business librarians had tenure at their institution. Only 37.4 percent of respondents indicated that librarians at their institutions were required to publish scholarly articles. Average numbers of publications as reported by respondents are two refereed articles, 0.27 books, and 4.5 nonrefereed articles. Table 9 shows the distribution of self-reported numbers of publications.

\section{Comparison with Earlier Research}

In 1986, Kendrick surveyed 162 business librarians using Barron's Guide to Gradu-

TABLE 3

Business Librarians with Library Science Degrees and Second Master's Degrees in Economics or Business

\begin{tabular}{lcll}
\hline \hline Degree & Frequency & Total & Percent \\
\hline Master's degree in library science & 146 & 147 & 99.3 \\
Second master's in economics or business & 35 & 147 & 23.8 \\
\hline
\end{tabular}




\begin{tabular}{|lcc|}
\hline \multicolumn{3}{c|}{ TABLE 4} \\
\multicolumn{1}{|c}{ Business Librarians with Doctoral Degrees } \\
\hline \hline Subject Area & Frequency & Percent \\
\hline Humanities & 2 & 33.33 \\
Social sciences & 2 & 33.33 \\
Sciences and engineering & 0 & 0.00 \\
Professional schools & 1 & 16.70 \\
Business & 1 & 16.70 \\
Total & 6 & 100.00 \\
\hline
\end{tabular}

likely to have higher salaries than library jobs. The 1999 average starting salary for MBA graduates from top U.S. business schools was between $\$ 66,000$ and 106,000, compared with an average starting salary for librarians of $\$ 33,682 .{ }^{17,18}$ The average salary of $\$ 55,806$ for special librarians is less than the starting salary for MBA graduates. ${ }^{19}$ Although the

ate Business Schools, which listed more than 550 business schools. ${ }^{16}$ The authors randomly selected and surveyed 147 business librarians from more than 385 AACSB business schools in the United States. The authors chose AACSB-accredited schools because a set of criteria (including library support) is used to ensure the quality of business schools. The authors believe that AACSB-accredited schools are most likely to have adequate support for their business libraries, including qualified business librarians.

As shown in table 10, despite the small variations between these two surveys, there does not seem to be any significant changes in number of business librarians with formal academic training in the field of business within this fifteen-year period.

\section{Discussion}

The results of this survey show that a large majority of business librarians in academic libraries do not have the kind of expertise in business or economics that would be associated with formal training in those fields. These findings make more sense when placed in the context of other developments in the area of business information.

Business graduates are able to move directly into jobs in commerce and industry without having to obtain additional academic qualifications. Such positions are data on salaries are not totally consistent for comparison, they do reflect the fact that librarianship is not in a very advantageous competitive position when compared with business jobs. Accordingly, it is not surprising that relatively few academic business librarians have business degrees.

In addition, Gillian Allen demonstrated that business students have different values than library school students do. ${ }^{20}$ These differences may make it even less likely that business graduates will be attracted to business librarian positions.

Moreover, contemporary business librarians are faced with a number of interesting developments in their area of specialization. Competitive intelligence has developed as a separate subfield of business information work, and there is an emerging profession and body of professional literature for this subfield. Information resources management, an important aspect of business information work, has been augmented by knowledge management as a separate field and discipline. As management information systems have

\begin{tabular}{|lcc|}
\hline \multicolumn{3}{|c|}{$\begin{array}{c}\text { TABLE 5 } \\
\text { Business Librarians with Other Second } \\
\text { Master's Degrees }\end{array}$} \\
\hline \hline Subject Area & Frequency & Percent \\
\hline Humanities & 27 & 65.9 \\
Professional schools & 8 & 19.5 \\
Social sciences & 5 & 12.2 \\
Science and engineering & 1 & 2.4 \\
\hline Total & 41 & 100.0 \\
\hline
\end{tabular}




\begin{tabular}{|lc|}
\hline \multicolumn{2}{|c|}{$\begin{array}{c}\text { TABLE 6 } \\
\text { Nondegree Courses Taken } \\
\text { Business Topics }\end{array}$} \\
\hline \hline Subject Area & Number \\
\hline Accounting & 19 \\
Human resource management & 17 \\
Business information sources & 15 \\
Management & 15 \\
Computer applications for business & 13 \\
Finance & 13 \\
Economics & 11 \\
Marketing & 8 \\
Business law & 6 \\
Statistics & 6 \\
Strategic management & 4 \\
Public administration & 4 \\
International business & 2 \\
Real estate & 1 \\
Tax & 1 \\
Banking & 1 \\
Entrepreneurship & 1 \\
\hline
\end{tabular}

- Almost all academic librarians have an MLS, but a large majority of them do not possess academic degrees in business.

- Large-scale recruiting of business graduates into librarianship is unlikely to be successful because of economic and personal factors.

- Some library schools are centers of research and teaching in business information.

\section{Survey of Instructors of Business Information Courses}

From these considerations, the authors concluded that LIS schools might be able to help business librarians achieve some of the expertise they need by teaching business information. With this in mind, the authors surveyed instructors of business information courses in library schools to see what they are teaching.

grown and their scope expanded by electronic commerce and business-to-business Internet systems, a new field of management informatics has been created. This includes data-mining from large and var-

The authors wonder whether more and stronger partnerships between schools of business and schools of library and information science might provide at least one solution for academic business librarians.

ied data resources, and using equally varied information resources for environmental scanning. Education and research in these emerging areas are focused in schools of library and information science (LIS) or in collaborations between those schools and schools of business.

The picture that emerges from the findings of this survey and from these related considerations is as follows:

- Specialized knowledge of business is needed by academic business librarians.

\section{Methods}

The authors first sent letters and e-mail messages to the deans of ALA-accredited LIS schools that provide business information courses, requesting the names and e-mail addresses for instructors of business information, with a return rate of fifty responses. Survey questionnaires were then sent to instructors via e-mail, with a return rate of eighteen responses.

The instructors were asked for their opinions on business subject knowledge and business information sources that might be covered in a business information course in a library school curriculum.
TABLE 7

\section{Length of Time in Current Position}

\begin{tabular}{lcc} 
Time Length & Frequency & Percent \\
\hline 1-5 years & 46 & 31.3 \\
6-10 years & 35 & 23.8 \\
10-15 years & 26 & 17.7 \\
More than 15 years & 40 & 27.2 \\
\hline Total & 147 & 100.0
\end{tabular}




\begin{tabular}{|lcc|}
\hline \multicolumn{3}{|c|}{ TABLE 8 } \\
Previous Positions \\
\hline \hline Previous Positions & Frequency & Percent \\
\hline Reference & 46 & 31.3 \\
Special librarian & 17 & 11.6 \\
Technical services & 16 & 10.9 \\
Government document librarian & 8 & 5.4 \\
Library director & 5 & 3.4 \\
Paraprofessional & 3 & 2.0 \\
Corporate librarian & 5 & 3.4 \\
Business librarian & 5 & 3.4 \\
Bibliographer & 3 & 2.0 \\
No previous position indicated & 39 & 26.5 \\
\hline Total & 147 & 99.9 \\
\hline
\end{tabular}

business areas, such as production function, futures markets, insurance, and real estate. Overall, instructors tend to think that subject knowledge is important to teach in their courses. However, the amount of coverage of more specialized and technical topics is likely to be less than the basic and foundational topics. This interpretation is supported by an analysis of the number of respondents who said that they were "not sure" whether certain topics would or should be covered in their courses. The specialized and technical topics received more "not sure" responses than did the mainline business topics.

The authors classified subject knowledge in business in the following areas: accounting (financial accounting and managerial accounting), economics (macroeconomics and microeconomics), finance (corporate finance, financial institutions and markets, and investment), marketing, management, international business, real estate, and insurance. Each subject field was further broken down into approximately one hundred topical areas that the authors felt were important to understand business information production, organization, and interpretation. To rank the importance of subject knowledge, a scale of 1 through 5 was used, with 1 indicating "minimal importance" and 5 indicating "highly important." Instructors were asked to use $N$ to indicate "not sure."

\section{Findings}

The survey findings show that, in general, instructors ranked macroeconomics, management, marketing, financial accounting, finance, and international business higher (above 3.00) than microeconomics, managerial accounting, real estate, insurance, and some specialized areas of finance. Low scores (below 3.00) appeared in the categories that are more technical, analytical, and specific

\begin{tabular}{|lcc|}
\hline \multicolumn{3}{|c|}{ TABLE 9 } \\
Number of Publications \\
\hline \hline Publications & Frequency & Percent \\
\hline Refereed articles & & \\
$\quad$ None & 79 & 53.7 \\
1-5 & 52 & 35.4 \\
More than 5 & 16 & 10.9 \\
\hline Total & 147 & 100.0 \\
Books & 128 & 87.1 \\
None & 11 & 7.5 \\
One & 8 & 5.4 \\
More than one & 147 & 100.0 \\
\hline Total & & \\
Nonrefereed articles & 53 & 36.1 \\
None & 54 & 36.7 \\
1-5 & 21 & 14.3 \\
6-10 & 19 & 12.9 \\
More than 10 & 147 & 100.0 \\
\hline Total &
\end{tabular}

\section{Summary and Conclusion}

Subject expertise is an important factor in determining the quality of information services offered by business librarians in academic libraries. This investigation demonstrated that academic business librarians have taken a variety of approaches to obtaining the needed expertise. Fifteen percent of respondents have an undergraduate major in business, an additional 15.8 


\begin{tabular}{|c|c|c|}
\hline \multicolumn{3}{|c|}{$\begin{array}{c}\text { TABLE } 10 \\
\begin{array}{c}\text { Educational Backgrounds of Business Librarians in } \\
2001 \text { and } 1986 \text { Surveys }\end{array} \\
\end{array}$} \\
\hline Category & 2001 Survey & 1986 Survey \\
\hline Survey list used & AACSB & Barron \\
\hline Total number of schools on the list & 370 (U.S. schools) & 576 \\
\hline Total number of respondents & 147 & 162 \\
\hline $\begin{array}{l}\text { Undergraduate major } \\
\text { in business or economics }\end{array}$ & $22(15 \%)$ & $17(11 \%)^{1}$ \\
\hline $\begin{array}{l}\text { Undergraduate minor } \\
\text { in business or economics }\end{array}$ & $5(5.3 \%)^{2}$ & $7(6 \%)^{3}$ \\
\hline $\begin{array}{l}\text { Master's degree in business } \\
\text { administration or economics }\end{array}$ & $35(23.8 \%)$ & $30(18.5 \%)$ \\
\hline \multicolumn{3}{|c|}{$\begin{array}{l}{ }^{1} \text { Total number of undergraduate majors in business administration, economics, accounting, } \\
\text { management, marketing, and finance. } \\
{ }^{2} \text { Five out of ninety-five with undergraduate minors. } \\
{ }^{3} \text { Seven out of } 116 \text { with undergraduate minors. Total number of undergraduate minors in economics, } \\
\text { accounting, and business administration. }\end{array}$} \\
\hline
\end{tabular}

percent have an undergraduate minor in business, and 23.8 percent have a master's degree in business or economics.

Coursework in business not leading to a degree is another way of obtaining subject expertise. An additional 9 percent of respondents reported having taken six courses or more, the equivalent to one year of academic study in business. All of these business librarians have an MLS. It is possible that they took courses in business information as part of that degree. However, the authors found that business information courses tend to focus on the major topics of business and to provide much less coverage of specialized and technical topics.

The overall picture, then, is of professionals working in a specialized area who are scrambling to obtain the expertise they need to function effectively in that context. The authors wonder whether more and stronger partnerships between schools of business and schools of library and information science might provide at least one solution for academic business librarians. One traditional approach would be a joint master's in business and library and information science. Another would be specialized a "business" track within library education. Recruitment of students with business backgrounds into library education could be improved. However, innovative solutions may be necessary. Jointly operated programs in business informatics or business information systems could help meet the needs not only of academic business librarians, but also information professionals in the corporate setting.

The focus here was on academic business librarians. The authors recognize that this is only one segment of the business information sector and encourage educators and business information professionals to work together to develop new approaches to the education of business information specialists.

\section{Notes}

1. Jean-Pierre V. M Herubel, “To 'Degree' or Not to 'Degree': Academic Librarians and Subject Expertise," College E Research Library News 52 (July-Aug. 1991): 437. 
2. Crit Stuart and Miriam A. Drake, "Education and Recruitment of Science and Engineering Librarians," Science and Technology Libraries 12 (summer 1992): 81.

3. Ibid, 82 .

4. Julie Hallmark, "Education for the Successful Geoscience Information Specialist," Science and Technology Libraries 17 (1998): 84.

5. Shirley Echelman, “Libraries Are Businesses, Too!” Special Libraries 65 (Oct.-Nov. 1974): 409.

6. Lewis-Guodo Liu, "The Emergence of Business Information Resources and Services on the Internet and Its Impact on Business Librarianship," Online Information Review 24 (May-June 2000): 234-54.

7. Special Libraries Association, "Competencies for Special Librarians of the 21st Century. Available online from www.sla.org/professilnal.cop.html.

8. Raya Fidel, "Searchers' Selection of Search keys: I. The Selection Routine. II. Controlled Vocabulary or Free-text Searching. III. Searching Styles," Journal of the American Society for Information Science 42 (Aug. 1991): 490-527.

9. Ingrid Hsieh-Yee, "Effects of Search Experience and Subject Knowledge on the Search Tactics of Novice and Experienced Searchers," Journal of the American Society for Information Science 44 (Apr. 1993): 161-74.

10. Ibid., 169.

11. Thomas Jacobson and David Fusani, "Computer, System, and Subject knowledge in Novice Searching of a Full-text, Multifile Database," Library and Information Science Research 14 (Jan.Mar.1992): 105. 1985).

12. Ellis Mount, University Science and Engineering Libraries (Westport, Conn.: Greenwood Pr.,

13. Meng Xiong Liu and Wei Wei, "Science/Technology Librarians in California: Their Background, Performance and Expectations," paper presented at the Special Libraries Association Annual Conference, Cincinnati, Ohio, 1993.

14. Christopher Hooper-Lane, "Spotlight on the Subject Knowledge of Chemistry Librarians: Results of a Survey," Issues in Science and Technology Librarianship, no. 23 (summer 1999).

15. Aubrey Kendrick, "The Educational Background and Work Experience of Academic Business Librarians," RQ 29 (spring 1990): 394-99.

16. Ibid.

17. U.S. News Online, “2001 Graduate Business School Rankings. Top Business Schools. 99’ Average Salary and Bonus." Available online from http://www.usnews.com/usnews/edu/beyond/gradrank/mba/gdmbat1.htm.

18. Association of Research Libraries, "Average Salaries and Average Years of Experience of Library Professionals in Libraries with Three-, Four-, and Five-Step Rank Structure." Available online from http://www.arl.org/stats/salary/1997-98/98intro.html.

19. Special Library Association, "2000 SLA Salary Survey on Special Librarians." Available online from

http://www.sla.org/content/memberservice/researchforum/salarysurveys/salsur2000/ index.cfm.

20. Gillian Allen, "Work Values in Librarianship," Library and Information Science Research (fall 1998): 415-24. 